\title{
Study on the Subject Service Mode of University Library
}

\author{
Haiyan Liu \\ Information Technology Institute, Jilin Agricultural University, Changchun 130117, China
}

haiyan_49@sohu.com

\begin{abstract}
This paper expounds the concept and connotation of subject service, and in the current university library subject service and the practice experience, the problems of the current university library subject service are analyzed, characteristics, on the basis of the subject service elements, constructing principles of inquiry, at the same time, also clearly the process of the implementation of the library subject service in value.
\end{abstract}

Keywords: University Library; Subject Service; Service Model.

\section{Introduction}

The advent of the era of big data users access to academic information environment and the way of content, and great changes have taken place. Users never leave home can in massive amounts of subject information resources to obtain the information you need. Library initiative to provide subject service, not only can effectively integrate a variety of information resources, implementing the resources sharing, discipline can effectively achieve the technology integration, integration of subject information resources, the integration of the information service and its ability to realize the collective wisdom, eventually to promote China joint service efficient, orderly and sustainable development, the discipline construction to make due contribution for colleges and universities. University library is the literature information center of the school, it is to serve the teaching and scientific research of the academic institutions, is the important base of school information and social information. The library work in colleges and universities is an important part of school teaching and scientific research work. The construction and development of colleges and universities library should be adapted to the construction and development of school, the level is an important symbol of overall level of schools.

The subject service, is user centered and launched a mutual exchange service model, it breaks the traditional literature according to the work flow organization of science and technology information, in accordance with the scientific research subject or field, the organization of information processing, so as to achieve efficient use of information, make the subject librarian and users with better, so as to improve the coordination between information service and user requirements and tasks. The basic connotation of the subject service is to make the information service more focused on the needs of users, to provide information services from the passive to the active part of the specific research activities. The starting point of the library and the target set in scientific research, make it more closely between information technology personnel and researchers of the partnership, the ultimate goal of subject service is to improve the information service support to user needs and user tasks.

\section{The necessity of developing the subject service in University Library}

\subsection{The necessity of library to adapt to the digital environment.}

Library as information collection and distribution center, no matter look from the amount of information resources have, or from the perspective of the types of information cover, the advantages of the library are unmatched by any other information institutions. In addition, with the rapid development of modern information technology, on the one hand, users less satisfied with based on the literature service, and more and more tend to be based on knowledge and knowledge service solutions. Digitalization and networking to acquire and process information, on the other hand, has become a kind of basic requirements and behavior habits, and the user wants to these services can be organically integrated into the teaching and scientific research process, can be used anytime and anywhere. Therefore, the construction of digital library is also more attention should be given to each 
subject, the university library must carry out subject service, the library resources, personnel and network equipment and other advantages are revealed, the subject service concept become an important guiding ideology of deepening the service function of the library.

\subsection{The subject service can promote the sustainable development of the library.}

The development of University Library under the influence will be affected by the traditional positioning on the one hand, university library service object is limited, and the rich information resources are limited in a small range, which makes the development of the library greatly affected. On the other hand, part of the lack of resources integration of university library is widespread lack of patent technology achievements, innovation and integration of information resources effectively, make the University Library in the innovation system of the depth and breadth is limited, which makes the development of the library is intermittent, integrated these two factors, sustainable development to prove that university library must start of service road.

\subsection{The inevitable requirement for the library to realize the function transformation}

The university library service mode and function, only in a simple processor status, but the service objects of University Library for the school teachers and students, the information needs of users with the subject clear, so it is very important that the interaction between readers and library processors and communication, not only to strengthen all kinds of resources for procurement and improve the utilization ratio of the library resources, but also can provide personalized professional services for readers, meet the needs of readers, fully embodies the "readers first" principle of service. At the same time, in the context of building an innovative country, the library should highlight its advantages in all aspects, therefore, the development of library science services is more urgent.

\section{The value of university library to carry out the subject services}

\subsection{Increase the use value of the library information resources}

In the era of big data, the library value is not limited to its material value, but the user using the implicit value created by the supply of information, which is the ultimate value of the library, to carry out the process of subject service is the subject librarian using its own books and information and professional knowledge, to the needs of the user as the center of resources, virtual network information resources of library information collection, selection, processing, restructuring and development, ultimately deep level of service provided to the user. In this process, on the one hand, the value of the library can be greatly reflected, the other people, when users use these hidden resources, but also to create more social value.

\subsection{To improve the library service value of regeneration}

The value of library readers is reflected in the application of the knowledge acquired from the library to the various fields of the society. But the flowers subject service model, subject librarian directly involved in the research process of readers, integrated with the needs of users, the formation of close communication, integrated information service focuses on providing high level continuous, comprehensive, and personality, and reader satisfaction research is embodied reader value. Thus, it is an urgent need to carry out the subject service in the field to realize the reader's value.

\subsection{Improve the quality of library services}

Make full use of library information resources and human resources advantages, to provide information services to the society, promote the development of science and technology, economic, scientific and technological innovation organization can get more value, changes in plants could also increase the value of the library. At the same time, with the progress of science and technology, China construction of the librarians in China also provides a good platform for realizing ego value, also will be more and higher to the requirement of subject librarians, through the construction of China, also will surely improve the quality of the library service. 


\section{The main features of the subject service of University Library}

If you follow the "checklist" your paper will conform to the requirements of the publisher and facilitate a problem-free publication process.

\subsection{Research character}

The university library school discipline and characteristic disciplines of experts and scholars, teachers and students, to determine the main target for the library subject service, and according to this group to carry out discipline service, from the service contents and service level to the service mode reflects the significant research.

\subsection{Academic nature}

The goal of the subject service and the idea of the subject service are derived from the subject construction, and will serve the purpose of the subject construction. To meet the needs of user information, the purpose of improving the ability of information processing is to promote the discipline construction and promote the development of the discipline.

\subsection{Informative}

Service is the eternal theme in the library, and based on the research, academic knowledge service is a high level of China library service improvement. Based on the subject of knowledge-based service is around the subject setting, especially the key discipline and characteristic discipline construction and to a depth of knowledge service, it through the use of all kinds of professional database library and its web site, take the initiative to push knowledge. At the same time, through the subject librarian in teaching and research of side tracking and personalized service demand analysis, provide a comparison and evaluation, analysis, integrated with reference value of extension knowledge information, help for teaching and scientific research personnel to realize knowledge discovery, knowledge innovation and knowledge acquisition.

\section{Subject oriented service model of University Library}

In summary, university library subject service model should be established on the basis of the user demand driven, dynamic, personalized service, information resources, and subject librarians in the library of the combination of the advantages of setting up the new image of the library through active service. When the subject user terminal through the network to retrieve information and knowledge to meet the individual needs of the situation, you can communicate with the subject librarians, expounds their needs and problems, solve problems, become the subject librarian provider of knowledge products, this whole process is a process of subject service.

\subsection{Accept user questions}

First of all, the subject service users, can be from the information resource library and information sharing in knowledge base retrieval and access required, which belongs to the most basic service level, as long as the user has the knowledge and skills will be able to achieve the retrieval basic. But when faced with complex disciplines of information demand, simple retrieval is unable to meet the needs of the user's own, and most of the teachers and students do not have the professional retrieval skills, this time will pass to the subject librarian real-time consultation, two communication, subject librarians help according to the needs of users information provided to solve the problem for the user. This process is the process of providing the subject librarian with a key level of service.

\subsection{User needs analysis}

Analysis of the information needs of users is the basis of subject service, librarian for different researchers and diverse information needs, providing personalized, discipline, knowledge of the subject librarian service is the focus of the work of discipline, is an important feature of the service. Subject service must be established on the basis of the correct analysis of academic information needs of users; librarians can through the questionnaire survey, citation analysis, a variety of ways to visit scientific research personnel to understand the user's information needs accurately. Subject librarians in accepting the subject needs of users, the first to determine the subject of research stage, in different stages of research subject librarians need to establish different service strategies. In different stages of 
research, subject librarians to continually improve and communication with users, can also potentially implicit demand through to the subject blog, blog, etc., the user community deep mining users, users in the research and in-depth study, with potential implicit demand households become dominant demand. In this way, subject librarian will be able to more clearly understand the user's goals and needs, analysis and planning a more suitable for users of the subject of service strategy.

\subsection{Service strategy formulation}

After completing the user requirement analysis job, subject librarian users to formulate the corresponding service strategy for discipline. Subject librarians can choose the right tools and information resource to obtain the required information, after washing, screening, sorting, organization, analysis, finalize the design, the final products provide users with knowledge.

\subsection{User information feedback}

Feedback is a necessary stage of library service, which has an important role in the sustainable development of library science service. On the basis of collecting feedback, we will analyze, adjust, modify, and make the service more satisfied with the user. After receiving the final service provided by the subject librarian, the users need to feedback the use effect of the subject service product after a period of time. If the results are satisfied, the service is temporarily closed, and then the subject librarian to track the progress of the project, etc. Conversely, if you are not satisfied with the service, the subject librarian but also for the user's comments and suggestions to develop a service strategy, strengthen communication with the user to provide more suitable for the user's service products.

\subsection{Record update}

Provide users with personalized service of subject librarian affirmed, subject librarian, collation, analysis of subject knowledge service, and carries on the classification to the shared knowledge base, knowledge base is updated at any time for sharing, improve and supplement, for future optimization, more convenient for the user to provide related information.

\section{Conclusion}

This article through to the relevant theoretical knowledge of China library service analysis and comparison, to determine the concept of university library subject service, system and service mode, and analyzes the necessity and value of library services in China, China is inevitable trend in the development of library service, library should combine their own conditions, take positive coping strategies, to adapt to the change of user information demand as the goal, improving librarians' quality, perfecting the management mode actively, driven by user's demand to information environment, strengthen communication and exchanges between subject librarians and users, the construction of the service system of high quality in China.

\section{References}

[1] Xiaoen Jin, Bangyou Ding. Research on the subject service mode of University Library under the environment of "all media". Journal of Chongqing University of Science and Technology (Social Sciences Edition). (2016) No.1, p.125-127.

[2] Wenfen Jiang. Practice and Thinking on the subject service of University Library in China. Library and Information. (2010) No.4, p.138-140.

[3] Jiayin Li. Probe into the discipline service mode of University Library. Heilongjiang local Chronicles. (2015) No.1, p.313-314. 